\title{
Black Beethoven and the Racial Politics of Music History
}

\author{
Nicholas T. Rinehart
}

\section{The Question}

Was Beethoven Black? He surely wasn't, but some insist otherwise. The question is not a new one-it has been rehashed over the course of several decades, although it never seems to have caused much of a stir in any public intellectual debates. Indeed, what is perhaps most fascinating about this question is that is has remained somewhat under the radar despite its stubbornness. Nobody really thinks Beethoven was black. And only a few have even stumbled upon the possibility. That Beethoven may have been black is pure trivia-a did-you-know factoid for the classical music enthusiast. The composer ranks with Alexanders Pushkin and Dumas as one of history's great ethnic surprises, with the obvious exception that Beethoven wasn't ethnic. He was simply swarthy.

The logic goes something like this: Beethoven's family, by way of his mother, traced its roots to Flanders, which was for sometime under Spanish monarchical rule, and because Spain maintained a longstanding historical connection to North Africa through the Moors, somehow a single germ of blackness trickled down to our beloved Ludwig. This very theory-that Beethoven was descended from the Moors-has reappeared in several works throughout the twentieth century. Jamaican historian Joel Augustus Rogers (1880-1966) popularized this theory in several writings around midcentury, but the birth of the myth can be traced back further to approximately 1915 or even earlier according to music historian Dominique-René de Lerma, the world's leading scholar on classical composers of color. Rogers asserted in his provocative and controversial works such as the three-volume Sex and Race (1941-44), the two-volume World's Great Men of Color (1946-47), 100 Amazing Facts About the Negro (1934), Five Negro Presidents (1965), and Nature Knows No Color Line (1952), that Beethoven-in addition to Thomas Jefferson, Johann Wolfgang von Goethe, Robert Browning, and several popes, among others-was genealogically African and thus black. Musicologist Donald Macardle and de Lerma both refuted this possibility with several decades between them. De Lerma also authored a brief account 


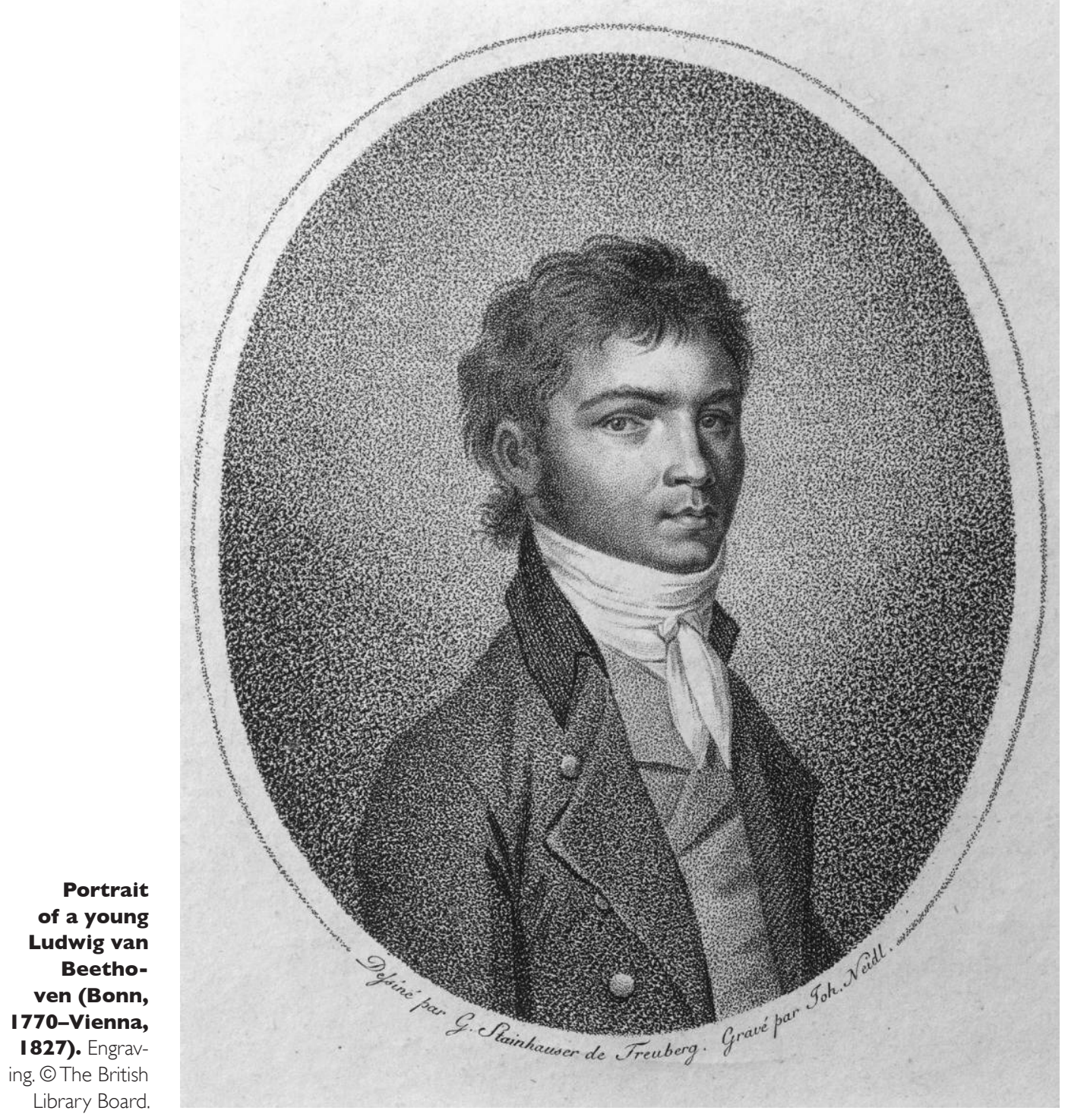

of this historical contestation in 1990 in an article entitled "Beethoven as a Black Composer" for the Black Music Research Journal. But the myth of Beethoven's hidden ethnicity still lingers in contemporary culture. Nobel laureate Nadine Gordimer published a short story collection in 2007 called Beethoven Was One-Sixteenth Black: And Other Stories. Novelist Darryl Pinckney hoped to refute Rogers once and for all in Out There: Mavericks of Black Literature (2002), based on his Alain Locke Lectures at Harvard University. Pinckney declares simply, "We don't need to claim Beethoven.” 
Surprisingly enough, a recent blog post has once again sparked interest in the historical question of Beethoven's ethnic heritage. An intellectual rigor in that article is, of course, basically nonexistent. But it deserves mentioning simply because it has been somewhat widely circulated throughout the "blogosphere" and even considered legitimate despite its intellectual laziness. Author "Ron01" writes on his blog on open.salon.com:

In an age where history is seriously being rewritten, new information is coming forth that is shocking intellectual sensitivities. What was once considered written in stone is now melting away with the discovery of facts that heretofore have been hidden or omitted; things so different that they are generally classified as controversial or unusual. That brings us to the topic of this post; the true identity of Ludwig van Beethoven, long considered Europe's greatest classical music composer. Said directly, Beethoven was a black man.

Although the author claims that the "presentation of verifiable evidence is compulsory" to support so contentious a claim, anecdotal descriptions of Beethoven's facial features by his contemporaries is all the evidence history can provide. He was said to have "Negroid traits," to bear "strong resemblance to a mulatto." He was called casually "the Spaniard" on account of his dark complexion. His hair was said to be "thick, bristly [and] coal-black." As such, the historical fascination with the journey of one lock of Beethoven's hair-the subject of the book Beethoven's Hair: An Extraordinary Historical Odyssey and a Scientific Mystery Solved (2001) and the ensuing 2005 film and accompanying interactive website-perhaps makes this very strand the world's most coveted kink. A 1991 issue of Newsweek referred to him as the "great Negro composer Beethoven.”

The anonymous blog writer's most striking claims actually recycle racist tropes as evidence of Beethoven's supposed blackness. Contemporary accounts of the composer's "Negroid" traits are marshaled with great haste to demonstrate his African roots. Even more intriguing and disturbing is the number of online commenters who have debated whether Beethoven's appearance was truly "Negroid" - as if the racialized typologies of yesteryear's physical anthropology had reared their ugly heads. As if Samuel A. Cartwright had joined an online message forum. As if this revisionist reeducation had reinstituted the American 
School of Ethnography. Did Beethoven have drapetomania? His death mask, the author writes, "clearly reveals his broad, flat nose." But racial science gives way to racial supposition. His pupil Carl Czerny described Beethoven as having "coal-black hair, cut à la Titus, [which] stood up around his head"- "sounds almost like an Afro," explains the writer in a bracketed interjection that also completely ignores the Roman imperial reference. Another source mentions Beethoven's "thick, bristly coalblack hair" which "in today's parlance," we are reminded, "we proudly

To attempt to reveal a musicological link between the Waldstein sonata and reggae is pure absurdity, nothing less. call . . . 'kinky." Almost more convincing is the claim that Beethoven's residence in Vienna was called the "House of the Black Spaniard." A young friend of the composer, Gerhard Breuning, published a memoir of his tender friendship with the aging Beethoven entitled Aus dem Schwarzspanierhause in Vienna in 1874. A brutally literal translation of Breuning's title would indeed be "From the Black Spaniard's House," but a 1992 translation by Henry Mins and Maynard Solomon was published by Cambridge University Press as Memories of Beethoven: From the House of the Black-Robed Spaniards. Somewhere along the way, not only was the German Schwarz taken to mean "a black man" or "having black skin" (which is itself extremely debatable given the plethora of racialized descriptors available in German), but the possible pluralization of Spanier was also lost completely. And because Beethoven would supposedly become angry when called "inferior," the author surmises, "Clearly, he must have been an exotic and at times disparaged presence in Germany and Austria." Yes, clearly. I don't mind being called inferior.

In addition to his facile recapitulation of classically racist ethnological essentializations regarding the composer's appearance, the author's most profoundly stupefying claim is that Beethoven's opus was inherently African in spirit and even anticipated jazz. Simply stated, "His music reveals a cultural connection to his African ancestry." And further- "The distinctive characteristic of off-beat accents, or syncopation" so central to Beethoven's revolutionary aesthetic "is intrinsic and integral to Black people's music making, which gives it a unique vitality and kinetic energy." The Grosse Fuge demonstrates this rhythmic Africanism, as does his final and arguably unfinished Piano Sonata No. 32 in C minor, Opus 111, which "sounds like the genesis of jazz." And the syncopated bass of the Waldstein Sonata "might inspire gospel music clapping" and "is also the same off-beat pattern used in reggae and HipHop music." We need not say that syncopation has permeated Western art music since its inception, whether in the form of a cadential hemiola appropriate to the Baroque era or in the several forms of off-beat waltz such as the Sarabande or Mazurka. Yet conjuring images of drum circles 
and part-playing, the writer mentions Beethoven's "prolific use of the syncopating kettle drum" in his symphonic work, thus making him "the first composer to invigorate European Classical Music with prodigious use of this decidedly inherent African rhythmic trait." These claims are so ridiculous that they verge on laughable. To attempt to reveal a musicological link between the Waldstein sonata and reggae is pure absurdity, nothing less. But the author goes on-and I will save you the pain of reading it here-to assert the African roots of all of Beethoven's formal musical innovations. All of this is to say on the one hand that Beethoven's great genius can be attributed to his blackness and on the other hand that a black man was the first to "deviate from the musical template of eighteenth-century rules and regulations," the first to "explore and exploit the virtuosic possibilities of the piano, which necessitated piano makers' building stronger, more durable instruments," and the first to "include a chorus in a symphony." By making Beethoven black, all of Beethoven's contributions to the trajectory of musical (and cultural) history are testament to black accomplishment. But Beethoven was not black.

If this particular anonymous blog post is indicative of a larger extra-academic trend (and there is certainly cause to believe that it is), then it illustrates exactly how historical revisionism has failed. That is, these claims attempt to revise something that doesn't need to be revised. So there is actually a complete desecration of historical and scholarly method disguised as righteous detective work. And this is obviously a problem because it demeans a) the proper study of history itself and b) acts of historical revisionism that are both good and true. They, too, illustrate the far-too-common propensity to reject more nuanced or complicated notions of ethnicity and interracialism in favor of an either/or construction of race along a strict black/white binary. Nowhere is the possibility and never is the suggestion that Beethoven was a mixed-race or interracial composer. He was either black or he was white. As J. A. Rogers argued initially in Sex and Race, "In short, there is no evidence whatever to show that Beethoven was white." As de Lerma has written, "No matter how circumstantial or speculative [J. A.] Rogers's arguments might be, they are certainly ardently posed and are most provocative for those who still think of a black/white dichotomy. They deserve notice." Almost three quarters of a century later, these arguments are still being "ardently posed" and they are still "provocative" and "deserve notice." And moreover, the blanket statement that "Beethoven was black" denies any distinction between belonging and genealogy in the formation or construction of racial or ethnic identity-black or otherwise. This repeated insistence also showcases how intellectual and historical debates are increasingly taking place in new places and spaces. A conversation sparked several decades ago and 
consequently put to death and revived and silenced again in academic circles has transcended to an afterlife beyond the realm of scholarship and historical method. These writers actively reject learned institutions, which they view with pointed skepticism.

Another widely circulated post sustaining the myth of Black Beethoven, this one on a Tumblr blog, asserts that history cannot be trusted

By making Beethoven black, all of Beethoven's contributions to the trajectory of musical (and cultural) history are testament to black accomplishment. But Beethoven was not black. because "It's written by people with power, and people with power, believe it or not, generally do not care about lying if it means keeping that power." And more than that, scholarly or intellectual institutions are complicit in that lie: "That is why the ancient Egyptians are shown as being incredibly light-skinned and the Moors are barely mentioned in many academic historical discussions." Perhaps we need not discuss at length that this writer's notions about Egyptian art are patently false-one need only sneak a peek at Werner Sollors' Neither Black Nor White Yet Both to learn that ancient Egyptian statues were colored according to the sex of the depicted figures (brick red for men, pale ochre for women) - and that the Moors are no secret to professional historians. Indeed, what is so surprising about this failed attempt at historical-revisionism-cum-black-achievement-literature is that it actually represents a very noticeable and thus significant trend in online debates throughout the "blogosphere." For when we make that transition from ivory tower to the dashboards of Tumblr and from CFPs to GIFs, we must forsake quality for quantity. What is most important is what is most abundant - available, observable, debatable.

The Tumblr post cited above is simply entitled "Beethoven Was Black." The author states frankly: "First of all, let's get this out of the way: Yes he was [black]. By today's standards, based on descriptions from people who met him, if you were shown a photograph of the real Beethoven and then asked to guess his race, I guarantee you 99\% would say 'black.' . . . If Beethoven were alive today, ancestry aside, he would be treated as a black man by society." Here we have another theory of race: at the very least, this writer tells us, Beethoven was-or would have been-functionally black. Regardless of the composer's actual genealogical makeup, he would have been black enough to be discriminated against had his blackness been more evident or more publicly expressed, or if he were American. De Lerma relates a conversation between Raymond Blathwayt and Samuel Coleridge-Taylor no later than 1907 in which that composer supposedly remarked that, ". . . if the greatest of all musicians were alive today, he would find it 
somewhat difficult, if not absolutely impossible, to obtain hotel accommodation in certain American cities." Another writer assumes in his post "Ludwig van Beethoven was Black . . . The Late Great Composer was a Black Man!!!" that "In the Southern States Beethoven would have been forced to ride in the jim-crow car." Perhaps the widespread appeal of this myth is the presumption on the part of many bloggers that Beethoven would not have been able to become Beethoven under certain other circumstances-most obviously that he could never have achieved such greatness in an American context. For whatever reason, these analyses-while leaning on the supposed veracity of Beethoven's African heritage-never problematize or praise or acknowledge how the composer was able to become Beethoven in a European context that must have (according to this logic) celebrated him despite his ambiguous or exotic origins.

Again, Beethoven's alleged blackness takes on a more thoroughly political and social dynamic as the analytical emphasis swings from Moorish ancestry to implicit expressions of black camaraderie on behalf of the composer. If he was functionally black enough to experience discrimination according to our Tumblr author and Coleridge-Taylor, he was also functionally and somehow self-consciously black enough to identify with other people of color. De Lerma mentions another conventional historical suggestion of Beethoven's African roots: his friendship with Afro-Polish violinist George Bridgetower (a relationship reimagined by Rita Dove in her poem cycle Sonata Mulattica, yet Dove seems not to incorporate the myth of Black Beethoven into that narrative). Eerily echoing J. A. Rogers desperate claim that Beethoven's whiteness could not be proven, this Tumblr post relies upon reversing the central question of Beethoven's blackness from a hypothetical standpoint: "This post is meant to ask the question 'Why not?' 'You prove to me he wasn't!' is my automatic response to this." Here is counterfactual history at its worst. The burden of proof has sneakily shifted-we have instantly gone from the historical inability to substantiate myths of Beethoven's blackness to the inability to substantiate his whiteness. And more than that-we have gone from an accumulation of misunderstandings, subtle changes, minor covert acts of whitewashing in the first post I discussed to a coherent and collectively and self-consciously produced lie. And all of this righteous detective work-or, righteous empiricism, at it casts itself-indeed serves to open up a new vision of world history. The author decries the supposed widespread inability to accept Beethoven's blackness as “one simple explanation that wraps everything up in a nice bow and changes nothing other than [sic] reveal historical whitewashing. . .." The unwillingness to recognize that "Africa was a major player in World History rather than ... a secondary character in a Eurocentric version of World history" is "all kinds 
of problematic." And here's the kicker: "I could write a book on how racist that is."

If you'll allow me the digression: this blogospheric afterlife of Black Beethoven has begun to resemble similar online debates over the disputed racial identity of none other than Jay Gatsby. The whole Gatsby debacle was sparked by Carlyle V. Thompson, a professor at Medgar Evers College in Brooklyn, New York who interprets Fitzgerald's novel as a tale of racial passing akin to those by Charles Chesnutt and James Weldon Johnson. Thompson thus goes a step further than even Harvard critic John Stauffer's reading of Gatsby as an allegory of racial passing and instead insists that Jay Gatsby is a black man. He advances this theory in his book The Tragic Black Buck: Racial Masquerading in the American Literary Imagination-specifically in the chapter entitled "The Tragic Black Buck: Jay Gatsby's Passing in F. Scott Fitzgerald's The Great Gatsby," which is serendipitously the only section from the book accessible online through Google books_-and in an online article for Times Higher Education called "Why I believe Jay Gatsby was black." The tragedy of the whole ordeal is neither the historical whitewashing of American literary history generally or Fitzgerald's work specifically, nor is it the fact of Gatsby's alleged racial misfortune secretly embedded in the novel. What is so clearly tragic is that Thompson's interpretation verges on impossible, and his analysis is simply cringe-worthy. Perhaps expectedly, his attempt to reveal the latent blackness of American literature's most famous protagonist pales in comparison to the controversial, provocative, and still brilliant studies by Toni Morrison and Shelley Fisher Fishkin in Playing in the Dark and Was Huck Black?, respectively. These works powerfully demonstrate how African American culture and history and the legacy of American slavery have haunted American literary style and functioned as the bedrock for its development. (A somewhat similar or at least resonant theory with regard to the development of Western classical music has been put forth by Timothy Taylor in his book Beyond Exoticism: Western Music and the World.) And yet not only have Thompson's theory and subsequent debates been picked up by Salon.com and The Guardian online, but the many denizens of Tumblr and other blog-hosting sites have picked it up and run with it. This is all despite the fact that Gatsby is not black. After all, Fitzgerald is mostly deliberate about race in his novels-like the three "negroes" in the passing automobile in the last chapter of Gatsby, and the brief mention of Topsy from Harriet Beecher Stowe's novel in Tender is the Night. Racial difference is certainly a theme that haunts his work, that lurks in the corners - as Morrison and Fishkin have suggested more generally-but there is nothing in the text indicating that Gatbsy is black. This is not to mention that the formal resonances between Fitzgerald's novel and 


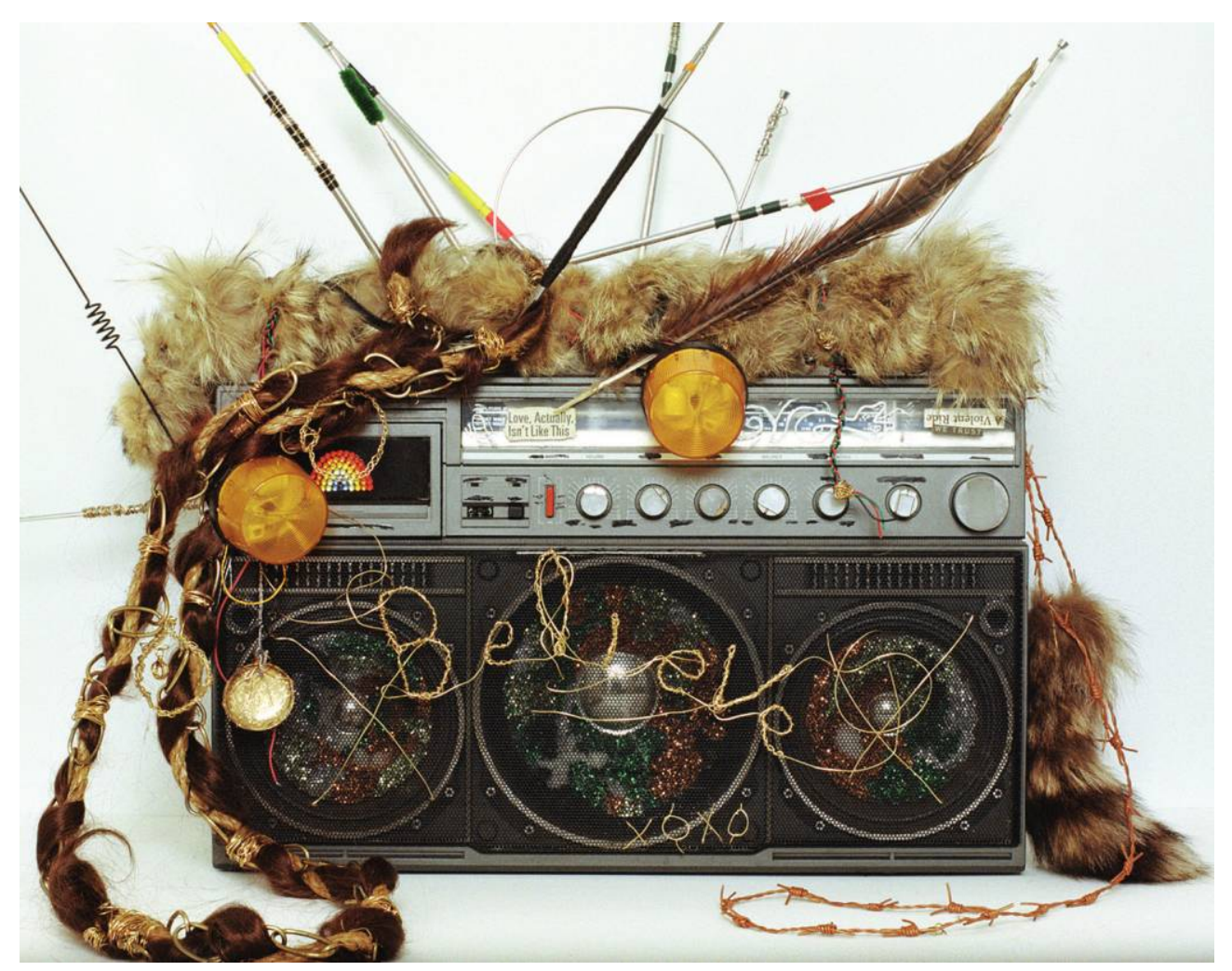

the interracial works of Chesnutt, Johnson, Nella Larsen, Frank Webb, Jessie Fauset, and Pauline Hopkins are few and far between. Still, the question has taken on a life of its own. One post is entitled emphatically, "The Great Gatsby Was A Story About A Black Man!" while the most widely circulated variation is simply "Jay Gatsby was black: an explanation."

And back to Ludwig: The fact that these simplistic historical rewritings have been read, shared, and reposted by thousands of internet users indicates that there is not only a growing interest in reviving this supposedly dead topic but also a growing belief in its veracity. Although the issue has been sufficiently settled by intellectuals like Darryl Pinckney and academics like de Lerma, the debate continues to resurface in non-academic spaces. Interestingly, one of the "frequently asked questions" listed on the Ira F. Brilliant Center for Beethoven Studies at San José State University website is: "Was Beethoven black?" A simple Google search for "black Beethoven" will return innumerable forum posts, articles, and blogs that address this question, often in an attempt to dispel once and for all Beethoven's false whiteness. One response to this line of questioning on wiki.answers.com states the following: 
"Despite who his ancestors were, one only has to listen to the symphonies and concertos, music the deaf composer probably never heard except in his own mind, to know that he was a genius who, to this day, transcends time, age, gender, and ethnicity. Listen, don't look. Music is colorblind."

Music may be colorblind, but is music history?

\title{
Beethoven's Black Sister
}

The figure of Black Beethoven provides ample material for several lines of questioning. First, what does it mean that Beethoven has been recast as a black composer in the twentieth and twenty-first centuries? Second, has this notion of "blackwashing" appeared elsewhere in music history, and why? And third, can we imagine Beethoven black?

If one allows the leap of imagination, the mirror image of black Beethoven is Judith Shakespeare. The latter is of course the famously profound hypothetical from Virginia Woolf's extended philosophical essay A Room of One's Own. Woolf introduces Shakespeare's sister as a historical case study in her devastating philosophical and political rumination on women's literature. For all intents and purposes, we can temporarily understand the "woman question" (women/literature) and the "race question" (race/music) as isomorphic. As Woolf endeavors to trace the absence of women in literary history, so we will briefly trace the absence of composers of color in standard accounts of classical music history. Woolf's governing question is this: if Shakespeare had a sister of equal artistic or literary genius, what would have become of her? Her answer is a grim portrait of oppression and lunacy:

\begin{abstract}
At last-for she was very young, oddly like Shakespeare the poet in her face, with the same grey eyes and rounded brows-at last Nick Greene the actor-manager took pity on her; she found herself with child by that gentleman and so-who shall measure the heat and violence of the poet's heart when caught and tangled in a woman's body-killed herself one winter's night and lies buried at some cross-roads where the omnibuses now stop outside the Elephant and Castle.
\end{abstract}

Woolf then expands from the given example of Judith to "any woman" and draws her dire conclusion: 
This may be true or it may be false-who can say?-but what is true in it, so it seemed to me, reviewing the story of Shakespeare's sister as I had made it, is that any woman born with a great gift in the sixteenth century would certainly have gone crazed, shot herself, or ended her days in some lonely cottage outside the village, half witch, half wizard, feared and mocked at. For it needs little skill in psychology to be sure that a highly gifted girl who had tried to use her gift for poetry would have been so thwarted and hindered by other people, so tortured and pulled asunder by her own contrary instincts, that she must have lost her health and sanity to a certainty.

My use of Woolf here may seem trite, but it is not-and it is certainly not irrelevant. The issue of women and literature that Woolf considers is analogous to the issue of women and classical music, with the critical difference being that the latter issue has never been seriously raised. What do we know about women composers throughout history? What if Beethoven had a sister? What if Beethoven had a black sister?

Allow me the digression. I would argue that there are at most three or four women composers that remain today in our popular musical imagination. They are Hildegard of Bingen (1098-1179), Francesca Caccini (1587-1641), Fanny Mendelssohn (1805-1847), and perhaps Nadia Boulanger (1887-1979). Even this much is a stretch. We could be generous and add Amy Beach (1867-1944).

Bingen and Caccini are known only to serious students of music history in universities and conservatories. Nadia Boulanger is remembered primarily as the greatest composition instructor of the twentieth century, but her own works are inexplicably neglected outright. Fanny Mendelssohn's story is indicative of greater trends in cultural history as written by Woolf. She is classical music's real Shakespeare's sister.

What do we know about women composers throughout history? What if Beethoven had a sister? What if Beethoven had a black sister? Possessing supposedly equal musical prowess and creative genius as that of her brother Felix-one of the great Wunderkinds of music history who penned the astonishing overture to A Midsummer Night's Dream at the tender age of seventeen-Fanny was forbidden from pursuing a career as a composer because she was a woman. Fortunately but also sadly her brother published some of her works under his own name. So 
we have very quickly arrived at the general fate of women and music. There are four outcomes: first, to be forgotten completely; second, to become esoteric in the extreme; third, to be overlooked or neglected; and fourth, to be overwritten by a man.

I think it is much the same case if we ponder the race question in classical music. Consider, for example, the case history of black composers. If we assume temporarily that Beethoven was black, we have again only three or four composers remaining in the popular imagination. Not including Ludwig himself, they are Joseph Boulogne Chevalier de Saint-George (1745-1799), Samuel Taylor-Coleridge (1875-1912), and William Grant Still (1895-1978). We could be generous and add George Walker, who in 1996 became the first African-American composer to win the Pulitzer Prize for Music. That, too, would be a stretch. But what do these composers tell us about race and classical music? Like their feminine counterparts discussed above, they've been forgotten, overlooked, and overwritten. What is perhaps most interesting, however, is not simply this clear fact but rather the exact manner in which they have been remembered. Woolf's depiction of lunacy, oppression, and death as the fate of women writers can be amended in the case of women composers and also composers of color: If Fanny Mendelssohn joined history under her brother's name, if her legacy was partly overwritten by his, then these black composers were overwritten by white composers. Boulogne is known to history as the "black Mozart." Taylor-Coleridge, who was in fact named after the great English poet, was called the "African Mahler." If we add "Black Beethoven," then we have several things to discuss.

\section{Blackwash the Whitewash}

There is a pregnant contradiction in this historical tendency to "whitewash" black composers, by referring to them or naming them after their notable Caucasian contemporaries. On the one hand, this whitewashing - as I have called it - is very clearly and undeniably insulting, belittling, and discriminatory. Why? Because it makes a black man a footnote to a white man. Because it erases the name and life's work of a black man and replaces them with those of a white man. Because music history is so dreadfully conservative and painfully rigid that it simply cannot admit three men of color to its lineup. That is, it cannot admit three additional names-such long names, so many extra words! - at the expense of the squeaky clean whiteness of the canon as it stands. That is why these composers, still confined to the realm of trivia and esoterica exactly because of their race, must be remembered only by the names of others. On the other hand-and I think quite 
spectacularly - this whitewashing has been claimed as a source of pride and accomplishment.

A few books have been published on the life of the Chevalier de Saint-George, who was also a violin virtuoso and accomplished fencer. There is The Black Mozart: Le Chevalier de Saint-George by Walter Smith (2004), two books for children-The Other Mozart: The Life of the Famous Chevalier de Saint-George by Hugh Brewster (2006) and Before There Was Mozart: The Story of Joseph Boulogne, Chevalier de Saint-George by Lesa Cline-Ransome (2011) —and one scholarly biography, Un contemporain atypique de Mozart: Le Chavalier de Saint-George by Michelle Garnier-Panafieu. There is another biography, Monsieur de Saint-George: Virtuoso, Swordsman, Revolutionary: A Legendary Life Rediscovered by

There is a pregnant contradiction in this historical tendency to "whitewash" black composers, by referring to them or naming them after their notable Caucasian contemporaries. Alain Guédé (2003). And then there is the film Le Mozart Noir: Reviving a Legend (2005), part documentary and part historical reenactment. All of these share a few things in common: first, they insist upon Mozart as a reference point; second, they claim this reference as a signifier of Boulogne's own genius; and third, they portray the composer as exceedingly beautiful, as if in a desperate effort to compensate for his historical obscurity_physically fit, perfect posture, so dignified holding his violin, with dark complexion and powdered wig. The DVD cover of Le Mozart Noir is particularly sexy.

Considerably less has been written about Taylor-Coleridge, with the exception of a recent publication, Black Mahler: The Samuel Taylor-Coleridge Story by Charles Elford (2012), which is more of a dramatized retelling of the composer's life than a biography. On his website, the author claims that he feels "duty-bound to remain loyal to the truth and sincerely hopes that Black Mahler will in some small way, revive an interest in this influential man who only ever saw himself as the English musician who lent his race a voice." This is all well and good, isn't it?

It is not, for the simple reason that music history must remember and acknowledge these composers on their own terms, not as the "other" versions of white men. What, then, of Black Beethoven? This tendency to "blackwash" Beethoven serves the very same purpose as this parallel tendency to whitewash black composers. To recast Beethoven as a black man-as it has been done repeatedly over the last several decades-is to claim him as a symbol of black accomplishment. More than that, it is to claim that black history has been unfairly whitewashed. And more than that, it is to claim that the history of classical music 
generally has been whitewashed in a fit of paranoia to conceal its secret blackness. None of these claims is legitimate. Beethoven was not black. But the claim to his blackness is startling and significant and should be the starting point for something equally profound.

In retrospect, we could see how whitewashing Boulogne and Taylor-Coleridge and blackwashing Beethoven are both part of a larger historical effort to assert the contributions of black composers to the The time has finally history of classical music. They are both come to make a single, claims to legitimacy, claims to accomplishconcerted, organized, ment, claims to genius, claims to participarigorous, dynamic, tion and inclusion. The figure of Black Beeand robust effort at it is a radically desperate attempt to accomfundamentally reshaping the classical canon. plish what historical whitewashing has totally failed in doing. This desperation, this need to paint Beethoven black against all historical likelihood is, I think, a profound signal that the time has finally come to make a single, concerted, organized, rigorous, dynamic, and robust effort at fundamentally reshaping the classical canon and reconsidering and reimagining the history of Western art music, period. 